\title{
The Effect of Leaves Extract of Mentha Sp. and Zizyphus Sp. on the Growth of Vigna Sp.
}

\author{
Abeer Mohammed Yousif Al-Hallap \\ Biology Dep., Education College for Pure Sciences - Ibn Al- Haitham, Baghdad University, Iraq \\ Corresponding Author: abeerheba@gmail.com.
}

\begin{abstract}
This experiment was conducted in green garden of Department of Biology / college of Education for pure science (Ibn Al-Hatham )for the growing season 2016-2017 to determint the effect of different concentration (10\%-20\%) of leaves extract of Mentha sp. and Zizphus sp. on some morphologyical and yield componenet of Vigna sp. the results showed that the concentration 20\% of leaves extract of Zizyphus sp. gave the highest values for germination speed, germination rate, dry and fresh $w t$. for the first harvest, and $N O$.of braches plant, plant height for the second harvest. While NO. of pod per plant gave the best values at the concentration $20 \%$ Mentha sp. leaves exrtract. The concentration 10\% Mentha sp. leaves extract gave the best values for wt. of pod per plant in comparision with control plants.
\end{abstract}

Keywords: leaves extract, Mentha sp., Zizyphus sp., Vigna sp.

\section{Introduction}

The Vigna L. belongs to the family Popilionaceae one of the largest families of flowering plants, with 450500 genera and about 12000 species (2 species in Iraq).

The plant is climbing prostrate or erect herbs with stipellale, pinnately trifoliolate leaves. In floteseace is raceme with yellow flowers and legume pod fruit containing seeds. The seeds and post of Vigna provide nutritious food of man and beast (1), this genus pantropical distribution it includes some well-known cultivated species (2). The extract from the leaves of the two plants that used in current study are Mentha L. and Ziziphus Mill., the first plant belongs to the family Limiaceae (Labiatae) it have erect square branches stems and arranged in opposite pairs aromatic leaves (3), which mainly contains volatile oil, resin tannins and flavonoids (4). The second one which belonging to Ramnaceae family (5), is a genus of spiny shrubs and trees.

The leaves are alternate and the fruit is an edible drupe yellow-brown often very sweet and sugary (6). The leaves of this plant chemical compositions are proteins and amino acids, flavonoids, alkaloid glycosides, saponins, sibers, tannims and phenolic acid (7).

\section{Materials and Methods}

The experiment was conducted in the Botanical Garden of the Department of Biology of the College of Education for Pure Sciences (Ibn Al-Haitham), University of Baghdad (2015-2016). The Vigna sp. was planted at 12/5/2015 by lines between the line and another $20 \mathrm{~cm}$, with 15 seeds per treatment and three replicates per treatment, used design of (R.C.B.D) and foliar application of plant with Mentha L. and Ziziphus Mill. plants extracts (20\%-10\%) at alone after the germination and when the plant reaches the stage (4-5) papers as follows:

1. Treatment of control.

2. Treatment of Mentha L. $10 \%$. 
3. Treatment of Mentha L. $20 \%$.

4. Treatment of Ziziphus Mill 10\%.

5. Treatment of Ziziphus Mill 20\%.

The following characteristics were studied (first harvesting) at 16/6/2015.

1. Ratio of germination $=\frac{\text { Number of germenating plant }}{\text { total number of seeds }} \times 100$

2. Speed of germination $=\frac{\text { Number of germinating plant }}{\text { Number of days science began of germination }}$

3. Soft weight

4. Dry weight

At the time of harvesting, the following characteristics were studied: on 23/8/2015.

1. Soft weight

2. Number of leaves

3. Plant height: The height of the plant has been measured from the surface of the soil and up to the highest point in the main branch by the ruler.

4. Number of corns per plants.

5. Weight of corns per plant.

6. Number of branches.

\section{Results and Dissection:}

The extracts were prepared as follows:

The weight of 10 grams of plant used (Mentha L. and Ziziphus) were taken alone and put into the electric mixer, grind the plant, then put $90 \mathrm{ml}$ of distilled water to get $10 \%$ concentration. As also for concentration $20 \%$, after that leave for half an hour to sedimentation the solid materials below and the fluid on top and to give the solid material all the material in which, then, the liquid at the top is taken and represents the extracts for that plant, with a concentration of $10 \%$ and $20 \%$ (9).

Table (1) showed that the speed of germination was significant affected and an increase in the treatment of Mentha L. was $20 \%$ concentration, with the rate of 1.033 and the treatment of the Ziziphus Mill. 20\% concentration with rate 1.33 and indicated that the dry weight of the first harvesting effect significantly and recorded increase in Mentha L. at concentration 20\%, with a rate of 41.78 and Ziziphus Mill. At concentration 20\% and a rate of 42.41. The component of the extracted essential oils and the active compounds may have contributed to encouraging growth and increasing the speed of germination and dry weight for the first harvesting $(10,11)$.

Table 2 shows that the number of leaves in the yield has been significant affected, with a $10 \%$ concentration in the treatment of Ziziphus Mill. and the rate of 33.50, as for the number of branches are significant affected in the treatment of Ziziphus Mill. concentration of 20\%, with an increase in this treatment and at the rate of 40.00, due to the increase in the number of sheets and the number of branches to efficient of photosynthesis and increase of plant material $(12,13)$.

Table 3 indicates that the plant's height was significantly affected, with an increase in the treatment of Ziziphus Mill. 10\%, with a rate of 2.107 and a concentration of $20 \%$ with a rate of 2.317. As also showed the number of corns per plant were significantly affected, Mentha L. recorded an increase in the $10 \%$ treatment at rate 29.00 and the concentration of $20 \%$ and the rate 36.00 . The treatment of Ziziphus Mill. 20\% and the rate 18.65, and the results also show that the weight of the corns per plant has been significantly affected as there has been an increase in the treatment of Mentha L. concentration of $10 \%$, at rate 35.40 and concentration of $20 \%$ at rate 18.65, while Ziziphus Mill. 
treatment $10 \%$, at rate 35.85 and $20 \%$ at rate of 23.63 . The increase in the number and weight of the corns per plant may be attributed to active compounds in the extracts that have a role in increasing vegetative growth $(12,14)$.

\section{References}

[1] Townsend, C. C. and Guest, E. (1974). Flora of Iraq legumeuales, Vol, (3): 581-585.

[2] Delagado-Salinas, A.; Thulin, M.; Posquet, R.; Weeden, N.; Lavin, M. (2011). Vigna (Leguminasae) sensulato: the names and identities of the American segregate genera. Am. J. Bot., 98(10): 1694-715.

[3] Jamila, F.; Mostafa, E. (2014). Ethnobotanical surrey of medicinal plants used by peqplein oriental to manage various ailments. Journal of Ethnopharmacology.

[4] Harly, R. M. (1975). Mentha L. in: Stace, C. A. ed hybridization and the flora of the British Isles: 387pp.

[5] Gennus Ziziphus Beijing, China: Catalogue of life china: 2008 Annual checklist Chima Reviewed Sptemberq. 2009.

[6] Flora Europaea: Zizphus query results. Royal botanic garden Edinburgh. Retrieved September 7, 2009.

[7] Gupta, M. K.; Bhandari, A. K. and Ramesh Kumar Singh, (2012). Pharmacogmostical evaluations of the leaves of Zizphus mauvitiana. IJPSR., 3(3): 818-821.

[8] Al-Kaisy, W. A. Amen, L.M. (2006). Physiological study of pens and cowpea treated with phytosanitary organizations. Diyala J., Vol.(22): 39-104.(In Arabic)

[9] Al-Obaidy, S. S. M. (2004). The effect of some crude plat extracts on the cell division. Submitted to the college of science for women university of Baghdad in partial fulfilment of the requirements for the degree of master of science in biology (in Arabic).

[10] Al-Kaisy, W. A.; Mahmood, R. and Twej S. T. (2010). Effect of GA3, vitamin C and cumin seed extract on seeds germination and growth of seedling of (Nigella saliva L.). Journal of Karbala University, Special number for the Scientific Conference .(In Arabic) .

[11] Al-Kaisy, W. A.; Mahmood, R. W. and Al-Hayani, E. H. (2013). Effect of Rosmarinus officinalis and Laurus nabilis extract on seeds germination and growth of seedling of Pisum sativum. A refereed scientific J. 19(79). (In Arabic).

[12] Amanullah, M. M.; Sekar, Sand Vicent, S. (2010). Plant growth substances in crop production. Asian. J. Plant. Sci., 9(4): 215-222.

[13] Nguyan, H. T. and Blum, A. (2004). Physiology and biotechnology integration for plant breeding. Marel Dekker Inc., New York: $628 \mathrm{p}$.

[14] Al-Hayan, E. H. H. (2013). Effect of spraying eucalyptus extraction and vitamin C and acetylsalicylic acid on some growth characteristics and yield of plant Vicia faba L. A refereed scientific J., 19(77). (In Arabic).

TABLE I: The Effect of Mentha L. and Ziziphus Mill. Leaves Extracts on the Ratio of Germination, Speed of Germination, Soft Weight and Dry Weight to the First Harvesting of the Vigna L. Plant.

\begin{tabular}{|c|c|c|c|c|}
\hline Treatment & $\begin{array}{c}\text { Ratio of } \\
\text { germination }\end{array}$ & $\begin{array}{c}\text { Speed of } \\
\text { germination }\end{array}$ & Soft weight & Dry weight \\
\hline Control & 40.0 & 0.767 & 5.49 & 32.89 \\
\hline Mentha L. 10\% & 63.0 & 0.933 & 4.34 & 26.47 \\
\hline Mentha L. 20\% & 70.0 & 1.033 & 5.62 & 41.78 \\
\hline Ziziphus Mill. 10\% & 50.0 & 0.800 & 5.61 & 35.02 \\
\hline Ziziphus Mill. 20\% & 88.7 & 1.33 & 5.80 & 42.41 \\
\hline LSD & 11.31 & 0.2897 & 1.200 & 5.028 \\
\hline
\end{tabular}


TABLE II: The effect of Mentha L. and Ziziphus Mill. leaves extracts on weight, number of leaves and number of branches of the second harvesting of the Vigna L. plant.

\begin{tabular}{|c|c|c|c|}
\hline Treatment & Soft weight & Number of leaves & Number of branches \\
\hline Control & 547.7 & 18.67 & 32.00 \\
\hline Mentha L. 10\% & 433.7 & 17.00 & 25.00 \\
\hline Mentha L. 20\% & 429.2 & 17.33 & 31.67 \\
\hline Ziziphus Mill. 10\% & 246.4 & 33.50 & 24.00 \\
\hline Ziziphus Mill. 20\% & 369.7 & 20.10 & 40.00 \\
\hline LSD & 59.24 & 4.981 & 6.348 \\
\hline
\end{tabular}

TABLE III: The effect of Mentha L. and Ziziphus Mill. leaves extracts on height plant, number of corns per plant and weight of corns per plant of the second harvesting of the Vigna L. plant.

\begin{tabular}{|c|c|c|c|}
\hline Treatment & Plant height & number of corns per plant & weight of corns per plant \\
\hline Control & 1.617 & 10.33 & 13.20 \\
\hline Mentha L. 10\% & 1.610 & 29.00 & 35.40 \\
\hline Mentha L. 20\% & 1.853 & 36.00 & 18.65 \\
\hline Ziziphus Mill. 10\% & 2.107 & 15.67 & 35.85 \\
\hline Ziziphus Mill. 20\% & 2.317 & 18.67 & 23.63 \\
\hline LSD & 0.4155 & 6.639 & 4.476 \\
\hline
\end{tabular}

